\title{
TALCOSIS OF UNUSUALLY RAPID DEVELOPMENT
}

BY

\author{
G. P. AlivisATOS, A. E. PONTIKAKIS, and B. TERZIS \\ From the Laboratory of Hygiene, Athens University
}

(RECEIVED FOR PUBLICATION JULY 9, 1954)

A diagnosis of talcosis, so far as we know, has not until now been made in Greece although this disease was first described by Thorel in 1896. This fact may have been due to the small number of talc workers in Greece, but since Thorel's description of talcosis as a definite clinical entity, pneumoconiosis due to talc has been the subject of investigations by many workers.* In most of the reports the writers were able to show the clinical, pathological, and radiological results of pneumoconiosis due to talc.

The present work is based upon the clinical and radiological findings and studies of pulmonary function in cases of pneumoconiosis due to talc after an uncommonly short exposure, the working conditions in the talc factories concerned, and the chemical composition and physical properties of talc powder.

\section{Case Reports}

Case 1.-Th. Mis., aged 38 years, left the army in October, 1950, with a clear chest radiograph and afterwards worked in a talc factory for 24 months without any break in his employment. In the factory he worked on electric mills used for pulverizing pieces of soapstone. He usually worked for eight-hour shifts but sometimes for 16-hour shifts as the factory was open day and night. He said that the air in the factory was always contaminated by a cloud of talc. (This fact was confirmed on inspection.) He did not wear a mask or protective clothing and therefore inhaled large quantities of talc powder. He could remove thick crusts of talc from the mouth and nostrils after some hours' exposure.

There was no family history of disease, and the patient had always been well. He had served in the army for more than four years and repeated preventive examinations never revealed any abnormality.

* Sand, ; Cuinningham, ; Hayhurst (1915); Zanelli (1931) Haynes (1931); Dreessen (1933); Stüber (1934); Dreessen and Dalla Valle (1935); Merewether (1934, 1935); Middleton (1936); Gardner (1938); Nuck and Szcepanski (1939); Policard (1940); Price and Carpenter (1940); Schulz and Williams (1+42); Siegal, Smith. and Greenburg (1>43): Sorel, Lasserre, and Salvador (1943); Porro and Levine (1946) ; Pruvost (1 146) ; Greenburg (1947) ; Perry (1947); Millman (1947); Parmeggiani (1948); Bruusgaard and Skjelbred-Knudsen (1949); McLaughlin, Rogers, and Dunham (1949); Hogue and Mallette (1949); Cavigneaux, Charles, Fuchs, and Tara (1950); Baader (1950).
For six months before admission he had complained of productive cough, mucopurulent sputum, and dyspnoea on exertion. He was compelled to stop work because of his symptoms 24 months after starting employment at the factory. As the result of a chest radiograph he was admitted to hospital in November, 1952, for observation.

In hospital clinical examination of the respiratory system revealed sibilant rhonchi, scattered areas of bronchial breathing, and impaired resonance in both lungs. He was apyrexial but dyspnoeic, especially on exertion, with cyanosis of the extremities. He had a productive cough and the sputum contained small grey bodies composed of talc. All sputum tests were consistently negative for $M$. tuberculosis by direct concentration, culture, and guinea-pig inoculation.

A full blood count was normal.

There was a rise in the sedimentation rate (30 in the first hour, 50 in the second, and 96 in 24 hours by the method of Westergren).

The pulse rate was usually 75 per minute at rest. The blood pressure was $125 / 80 \mathrm{~mm}$. $\mathrm{Hg}$. The electrocardiogram was normal.

A radiograph in November, 1952, showed numerous nodular shadows in both lungs, confluent in some areas. The general condition of the patient at this time belied the widespread radiological extent of the lesions. A radiograph taken in March, 1953, and all the radiographs and tomograms taken at intervals of one, two, or three months showed that the disease progressed from nodule type to "tumour-like" type of disease (Figs. 1 and 3).

A bronchogram revealed no abnormality (Fig. 2). Angiocardiography showed a spasm at the level of the superior vena cava and abnormal arborization of the pulmonary arteries. Investigation of respiratory function revealed pulmonary insufficiency (Tables 1 and 2).

These findings and the exclusion of any other probable disease enabled us to diagnose pneumoconiosis due to talc.

Case 2.-G. Greg., aged 30 years, was discharged from the army with a clear chest radiograph in 1951. He then began work in a talc mill. After 18 months at this work he complained of paroxysmal cough, mucopurulent sputum, dyspnoea on exertion, loss of weight, 
TABLE 1

BLOOD GAS FINDINGS AFTER EXERCISE AND AT REST IN PRESENT SERIES

\begin{tabular}{|c|c|c|c|c|c|c|c|c|c|c|c|c|c|c|c|c|c|c|}
\hline \multirow[t]{2}{*}{$\begin{array}{l}\text { Case } \\
\text { No. }\end{array}$} & \multicolumn{2}{|c|}{$\begin{array}{c}\text { Arterial } \\
\text { Blood } \\
\text { Oxygen } \\
\text { Content } \\
\text { (a, at rest ; } \\
\text { b, after } \\
\text { exercise) } \\
\text { (Vol. \%) }\end{array}$} & \multicolumn{2}{|c|}{$\begin{array}{c}\text { Arterial } \\
\text { Blood CO } \\
\text { Content } \\
\text { (a, at rest ; } \\
\text { b, after } \\
\text { exercise) } \\
\text { (Vol. \%) }\end{array}$} & \multicolumn{2}{|c|}{$\begin{array}{c}\text { Arterial } \\
\text { Blood } \\
\text { Oxygen } \\
\text { Saturation } \\
\text { (a, at rest ; } \\
\text { b, after } \\
\text { exercise) } \\
(\%)\end{array}$} & \multirow[t]{2}{*}{$\begin{array}{c}\text { Arterial } \\
\text { pO } \\
\text { (rest, } \\
\text { mm./ } \\
\mathbf{H g} \text { ) }\end{array}$} & \multirow[t]{2}{*}{$\begin{array}{c}\text { Arterial } \\
\text { pCO, } \\
\text { (rest, } \\
\text { mm./Hg } \\
\text { p = } \\
\text { part. } \\
\text { pres- } \\
\text { sure) }\end{array}$} & \multicolumn{2}{|c|}{ 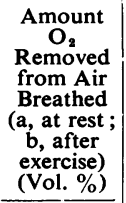 } & \multicolumn{2}{|c|}{$\begin{array}{l}\text { (a) Alveolar } \\
\text { Air Oxygen } \\
\text { Content } \\
\text { (b) CO, } \\
\text { Content } \\
\text { at Rest } \\
\text { (Vol. \%) }\end{array}$} & \multicolumn{2}{|c|}{$\begin{array}{c}\text { (a) Alveolar } \\
\text { Air } \\
\text { Oxygen } \\
\text { Content } \\
\text { (b) } \mathrm{CO}_{2} \\
\text { Content } \\
\text { after } \\
\text { Exercise } \\
\text { (Vol. \%) } \\
\end{array}$} & \multicolumn{2}{|c|}{$\begin{array}{c}\text { (a) Alveolar } \\
\text { pO at Rest } \\
\text { (mm./Hg) } \\
\text { (b) Alveolar } \\
\text { pCO } \text { at Rest }_{2} \text { at Rest } \\
\text { (mm./Hg) }\end{array}$} & \multirow[t]{2}{*}{$\begin{array}{c}\text { Aera- } \\
\text { tion } \\
\text { Gra- } \\
\text { dient } \\
(\mathrm{mm} . / \\
\mathbf{H g})\end{array}$} & \multirow[t]{2}{*}{$\begin{array}{c}\text { Trans } \\
\text { fer- } \\
\text { Gra- } \\
\text { dient } \\
\left(\begin{array}{c}\mathrm{mm} . / \\
\mathbf{H g})\end{array}\right.\end{array}$} \\
\hline & a & b & $\mathbf{a}$ & b & $\mathbf{a}$ & b & & & $\mathbf{a}$ & b & $\mathbf{a}$ & b & $\mathbf{a}$ & b & $\mathrm{a}$ & b & & \\
\hline 1 & $19 \cdot 1$ & $16 \cdot 6$ & 54.77 & $49 \cdot 32$ & 87 & $75 \cdot 7$ & 68 & 54 & 3.73 & $5 \cdot 13$ & 11.86 & 6.2 & 15.8 & 4.4 & $84 \cdot 56$ & $44 \cdot 2$ & 65.44 & 16.56 \\
\hline 2 & $15 \cdot 4$ & $12 \cdot 4$ & $48 \cdot 96$ & $40 \cdot 79$ & 81 & $64 \cdot 7$ & 80 & 45 & 3.63 & $5 \cdot 33$ & $13 \cdot 2$ & $6 \cdot 2$ & 14.6 & $5 \cdot 6$ & $94 \cdot 11$ & $4 \Delta \cdot 2$ & 55.89 & $14 \cdot 11$ \\
\hline 4 & $20 \cdot 22$ & $17 \cdot 5$ & 54 & $42 \cdot 3$ & 98 & 84.9 & 87 & 51 & $4 \cdot 73$ & 6.73 & $14 \cdot 2$ & 5.4 & $14 \cdot 2$ & $5 \cdot 2$ & $101 \cdot 2$ & 38.5 & $48 \cdot 8$ & $14 \cdot 2$ \\
\hline 5 & $18 \cdot 3$ & 15.77 & $52 \cdot 23$ & $45 \cdot 8$ & 93.8 & $80 \cdot 8$ & 85 & 50 & $4 \cdot 23$ & 6.43 & $14 \cdot 2$ & 5.4 & $13 \cdot 5$ & 5 & $101 \cdot 2$ & $38 \cdot 5$ & $48 \cdot 8$ & $15 \cdot 2$ \\
\hline 6 & $20 \cdot 31$ & 17.68 & 48.67 & 42.49 & 93.4 & $81 \cdot 3$ & 79 & 44 & 3.53 & $4 \cdot 73$ & 11.8 & $7 \cdot 1$ & $16 \cdot 2$ & 6.4 & $84 \cdot 13$ & 50.6 & $65 \cdot 87$ & $5 \cdot 13$ \\
\hline 7 & $16 \cdot 2$ & $13 \cdot 8$ & $46 \cdot 2$ & 36.4 & 82 & 73 & 81 & 42 & $4 \cdot 53$ & $5 \cdot 13$ & $12 \cdot 4$ & 6 & $12 \cdot 4$ & $4 \cdot 8$ & 88.42 & $42 \cdot 7$ & $61 \cdot 58$ & 8.42 \\
\hline $\begin{array}{l}\text { Normal } \\
\text { Values }\end{array}$ & $21 \cdot 5$ & $21 \cdot 5$ & $46 \cdot 7-53$ & - & $96+$ & $96+$ & 95 & 40 & $4 \cdot 5$ & $5 \cdot 5$ & 14 & $5 \cdot 5$ & - & - & 100 & 40 & 50 & 5 \\
\hline
\end{tabular}

TABLE 2

MEASUREMENTS ON VENTILATION IN PRESENT SERIES

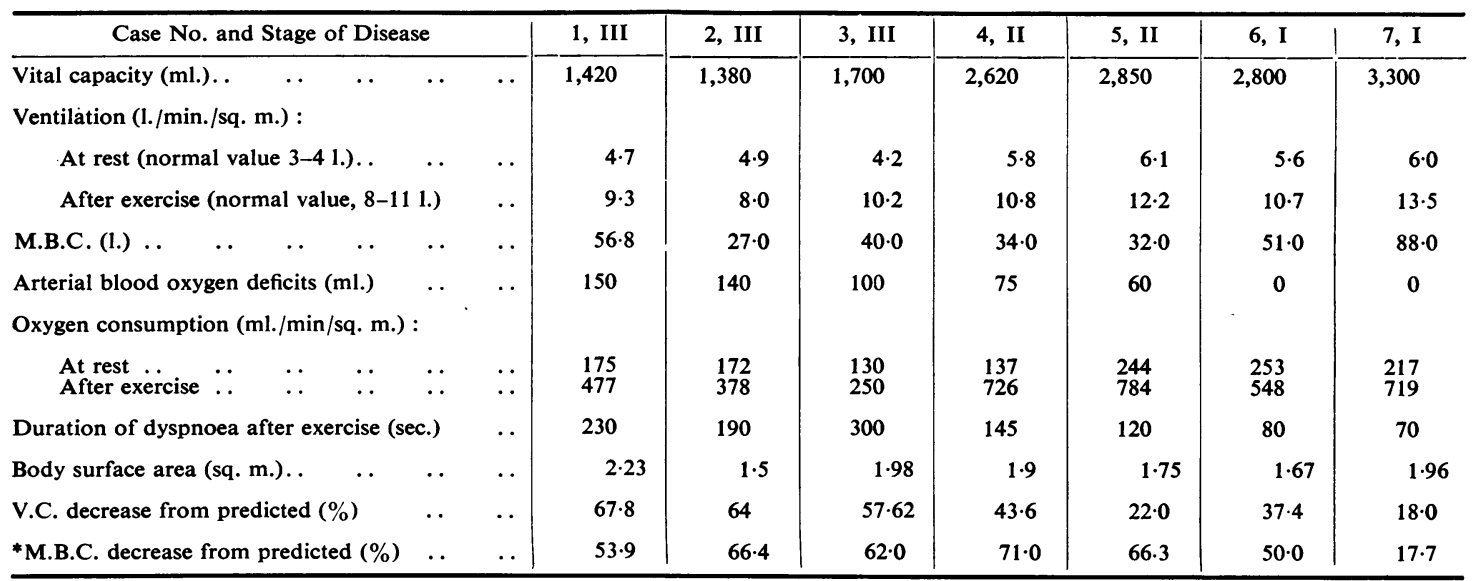

${ }^{*}$ Classification according to the description of Pancoast and Pendergrass (1931).

and general weakness. Examination of the respiratory system revealed dullness to percussion in some zones of both lungs and a few sonorous rhonchi and physical signs of emphysema. A radiograph showed bilateral mottling, confluent in some areas, and "tumour-like", appearances (Fig. 4).

All sputum tests, including guinea-pig inoculation, were consistently negative for $M$. tuberculosis. A full blood count showed a slight degree of anaemia. The sedimentation rate was 25 in the first hour, 40 in the second, and 82 by the twenty-fourth hour by the Westergren method.

Functional tests showed pulmonary insufficiency (Tables 1 and 2).
Case 3.-D. Thom., aged 49 years, worked for 60 months in a talc mill. Three years after starting work he complained of dyspnoea on exertion, cough, mucopurulent sputum, and general weakness. He gradually became more cyanosed.

Clinical examination in November, 1952, revealed impaired vesicular breathing in both lungs and bronchial breathing confined to both upper lobes, prolongation of expiration, and sibilant rhonchi. The radiological examination showed extensive " tumourlike" appearances on both lungs and bilateral diaphragmatic pleurisy (Fig. 5). All the sputum tests were consistently negative for $M$. tuberculosis. A full blood count was normal. The sedimentation rate in the first 
FIGs. 1 to 6.-Typical radiographs of patients in the present series showing mottling and tumour-like appearances characteristic of talcosis.

(1)

FIG. 1.

FIG. 2.

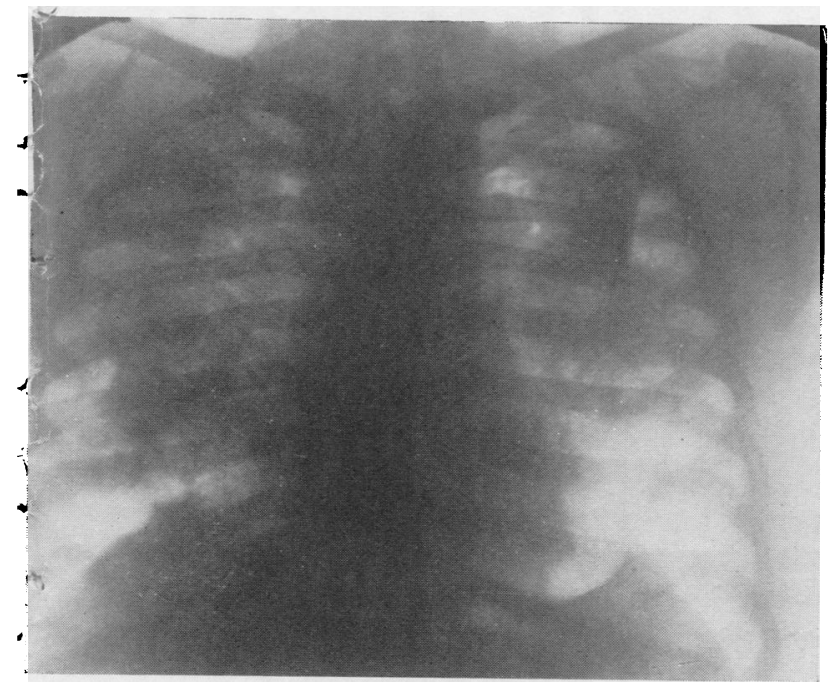

FIG. 3.

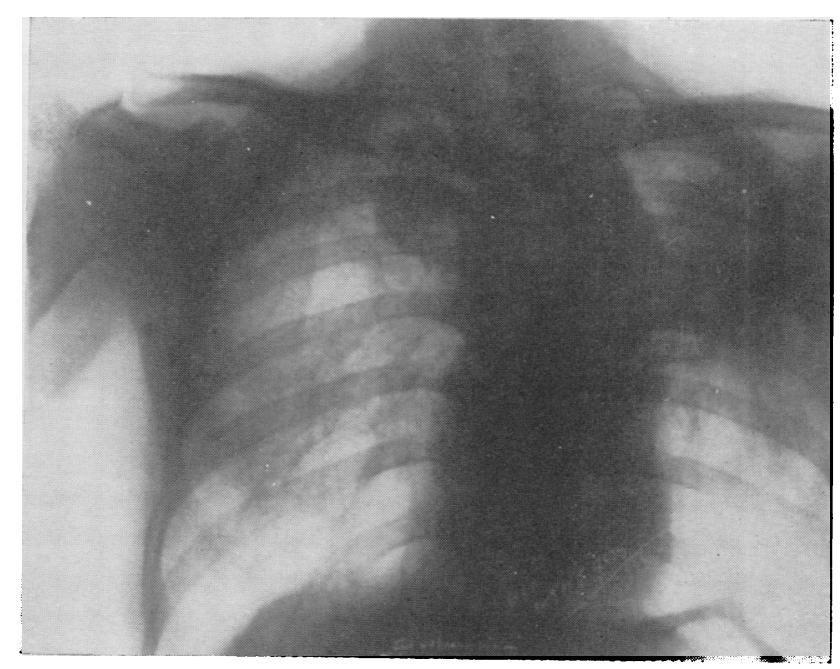

FIG. 4.

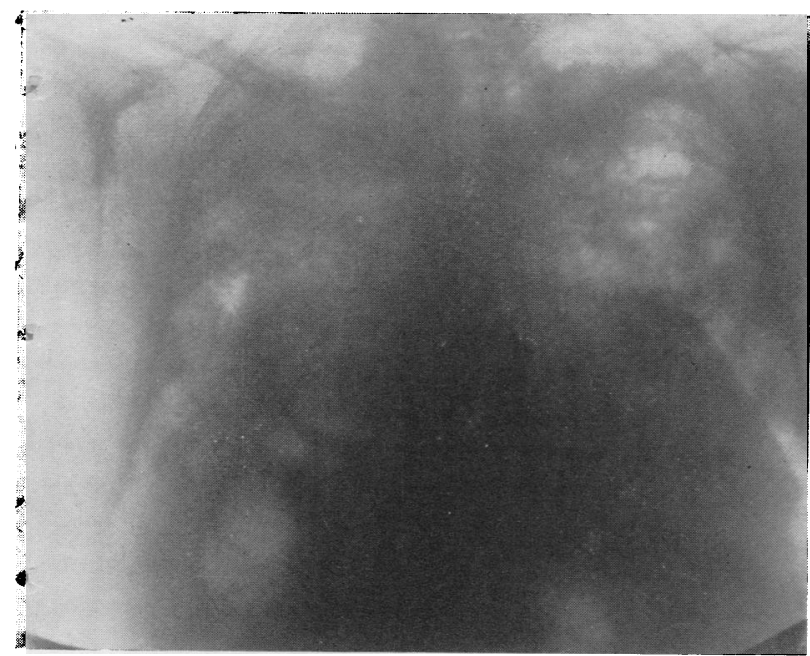

FIG. 5.

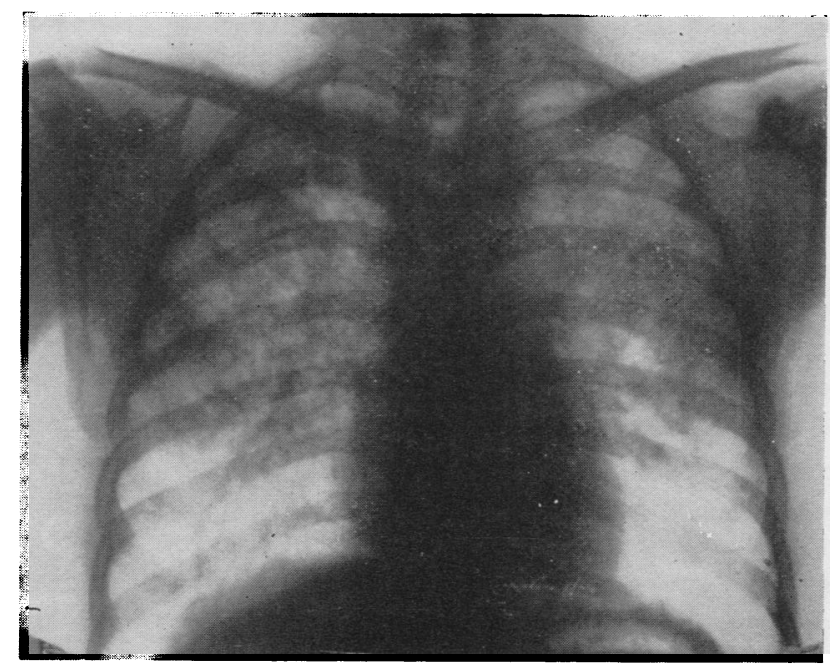

FIG. 6. 
hour was 38 , in the second hour 70 , and 116 by the twenty-fourth hour. Examination of respiratory function showed pulmonary insufficiency (Tables 1 and 2). The patient became worse and died from pulmonary failure in September, 1953. A post-mortem examination was carried out by Dr. Melissinos who reported that extensive massive fibrosis existed in both lungs, especially in the upper lobes. Numerous nodules were found which were confluent in some areas. On microscopic examination no evidence of tuberculosis was found. The pathological diagnosis was pneumoconiosis.*

Case 4.-K. Mak., aged 28 years, worked in a talc mill for 18 months. At the end of this time he complained of persistent cough, dyspnoea on exertion, and mucopurulent sputum, and for these reasons he left the factory. On examination talc particles were found in the sputum. He gradually continued to lose weight and strength. A clinical examination in February, 1953, revealed scattered bronchial breathing and rales in both lungs. The radiograph showed mottling in both lungs, confluent in some areas. All sputum tests were consistently negative for $M$. tuberculosis. A full blood count was normal. The sedimentation rate in the first hour was 16 , in the second hour 28 , and by the twentyfourth hour 41 . Respiratory function tests showed pulmonary insufficiency (Tables 1 and 2).

Case 5.-N. Chr. was a 22-year-old mill worker who had been in the talc factory for 26 months. After 18 months there he complained of dyspnoea on exertion, cough, and mucopurulent sputum. He gradually lost weight.

Clinical examination in April, 1953, revealed bronchial breathing in the upper lobes and a few sibilant rhonchi. The radiological examination showed mottling in both lungs, confluent in the upper lobes (Fig. 6). All the sputum tests were negative for $M$. tuberculosis. The sedimentation rate in the first hour was 22 , in the second hour 36, and by the twenty-fourth hour 72. Pulmonary function studies showed impaired function (Tables 1 and 2).

Case 6.-S. Sof. was a 35-year-old mill worker who had been in the talc factory for 22 months. Symptoms began 18 months after starting work in the factory. He complained of gradually increasing dyspnoea of effort, paroxysmal cough, and expectoration. Bodies made of talc were found in the sputum.

Clinical examination in April, 1953, revealed scattered areas of bronchial breathing and rales in both lungs. All sputum tests were consistently negative for $M$. tuberculosis. The chest radiograph revealed bilateral mottling especially in the right lung. The sedimentation rate in the first hour was 18 , in the second hour 25 , and in the twenty-fourth hour 42.

Pulmonary function was impaired (Tables 1 and 2).

Case 7.-G. Phr. was a 42-year-old mill mechanic who had been in the talc factory for $\mathbf{4 0}$ months. Symp-

* The pathological findings will be reported separately in detail by Dr. Melissinos. toms began 28 months after starting work in the factory when cough with a small amount of sputum and slight dyspnoea of effort appeared.

Clinical examination in January, 1953, revealed no abnormality. The chest radiograph showed reticulation and scattered mottling in both lungs. All sputum tests were consistently negative for $M$. tubercvlosis. The sedimentation rate in the first hour was 14 , in the second hour 28, and by the twenty-fourth hour 36 .

Pulmonary function was impaired (Tables 1 and 2).

Case 8.-S. Les. was a 38-year-old mill worker who had been in the talc factory for 16 months. He first experienced symptoms a few months before examination with the onset of dyspnoea on exertion, cough, and mucopurulent expectoration.

Clinical examination in June, 1953, revealed bronchial breathing in the upper lobes and a few sibilant rhonchi. The chest radiograph showed reticulation and confluent mottling in both lungs All sputum tests were consistently negative for $M$. tuberculosis. The blood sedimentation rate in the first hour was 15 , in the second hour 24 , and by the twenty-fourth hour 42 .

All the cases appeared by clinical, radiological, and laboratory examinations to be pneumoconiosis due to talc developing after an uncommonly short interval of exposure. The condition may have been due to the unusually irritating effect of inhalation of talc powder and to unhygienic working conditions.

\section{Conditions in Talc Factories}

The patients described above were working in either one or the other of the two talc factories in the Piraeus. One of these factories, that at Alav, obtained its raw material from the island of Tinos, the other, at Eviex, from the mountain Hymetos. The factories are old buildings, poorly ventilated, without any system of air conditioning. A permanent cloud of talc particles permeates the air. The workers remain in this atmosphere for eight-hour shifts, some of them working 16-hour shifts, as both factories are open day and night. Some of the workers, who slept on the premises near the mills, were exposed to a talc-laden atmosphere during sleep.

The manufacture of talc in these factories consists in breaking the raw material, soapstone, into smaller pieces by machinery or by hand. The smaller pieces are pulverized or powdered by an electric mill and the powder is then shovelled into sacks by collectors.

The employees do not wear masks or protective clothing and therefore inhale large quantities of talc powder and after some hours' exposure can remove thick crusts of talc from the mouth and nostrils. All the workers alternated on the different stages of the work. 
All lighting is artificial as daylight cannot enter through the closed doors and windows.

There are no recreation rooms or bathing facilities for the workers and they spend their rest periods in the same atmosphere as that in which they work.

The concentration of talc in the atmosphere was estimated with a Zeiss konimeter in different areas. Samples were taken from an area in the vicinity of the mills, from the stores, from the transport area, from the vicinity of the grinder. The results are shown in Table 3.

About 18 samples of air were taken from Eviex and 14 from Alav. In eight samples of air from the vicinity of the mills and from the transportation area at Eviex it was impossible to make a count because the concentration of talc in the atmosphere was too high and innumerable particles were found on the plaque of the Zeiss konimeter. In the other 10 samples the number of talc particles per litre of air was between 410,000 and $2,150,000$.

In two samples from the area near the mills at Alav the talc particles were also too many to count. In the other 12 samples the talc particles per litre of air were between 730,000 and 1,925,000 (Table 3).

TABLE 3

RESULTS OF AIR SAMPLING AT EVIEX AND ALAV

\begin{tabular}{|c|c|c|}
\hline \multicolumn{2}{|l|}{ Sampling Sites } & $\begin{array}{l}\text { No. of Talc Particles } \\
\text { per } 1,000 \mathrm{ml} \text {. Air }\end{array}$ \\
\hline Eviex & & \\
\hline $\begin{array}{l}\text { Vicinity of the mill (2 samples) } \ldots \\
\text { Store area (4 samples) }\end{array}$ & $\because$. & $\begin{array}{l}2,050,000 ; 2,150,000 \\
1,300,000 ; 850,000\end{array}$ \\
\hline $\begin{array}{l}\text { Transportation area (2 samples).. } \\
\text { Vicinity of grinder ( } 2 \text { samples) } \ldots\end{array}$ & $\begin{array}{l}. \\
\because \\
.\end{array}$ & $\begin{aligned} 550,000 ; & 410,000 \\
1,350,000 ; & 680,000 \\
580,000 ; & 530,000\end{aligned}$ \\
\hline $\begin{array}{l}\text { Vicinity of the mills ( } 7 \text { samples) .. } \\
\text { Transportation area (1 sample) ... }\end{array}$ & $\therefore$ & $\begin{array}{l}\text { Innumerable } \\
\text { Innumerable }\end{array}$ \\
\hline $\begin{array}{l}\text { Alav } \\
\text { Vicinity of the mills ( } 5 \text { samples) }\end{array}$ & $\cdots$ & $\begin{array}{l}980,000 ; \quad 940,000 \\
780,000 ;\end{array}$ \\
\hline $\begin{array}{lll}\text { Store area (3 samples) } & \ldots & \ldots\end{array}$ & .. & $1,925,000 ; 1,730,000$ \\
\hline Transportation area (4 samples).. & .. & $\begin{aligned} 1,250,000 ; & 915,000 \\
860,000 ; 810,000 & \end{aligned}$ \\
\hline Vicinity of the mills (2 samples) & .. & Innumerable \\
\hline
\end{tabular}

\section{Chemical and Physical Analysis of Talc Samples}

We performed chemical analyses of samples of talc made in the factories Similar samples were sent to Professor Paul Bonnevie (Copenhagen) for analyses and estimation of the diameter of the talc particles, and his findings by a refractographic method are as follows (Our own chemical quantitative analyses gave almost similar results. Both these analyses showed no free silicic acid in the samples.) :-
Sample 1 (Eviex, raw material from Hymetos) $51.4 \%$ of silicate salts estimated as silicic acid

Sample 2 (Eviex, raw material from Hymetos) $48.0 \%$ of silicate salts estimated as silicic acid

Sample 3 (Alav, raw material from Tinos) $49.4 \%$ of silicate Sample 3 (Alav, raw mat
salts estimated as silicic acid Sample 4 (Alav, raw material from Tinos) $48.0 \%$ of silicate

salts estimated as silicic acid
Sample 5 (Eviex, raw material from Hymetos) $51.3 \%$ of silicate Sample 5 (Eviex, raw materia
salts estimated as silicic acid

Sample 6 (Eviex, raw material from Hymetos) $52.2 \%$ of silicate salts estimated as silicic acid

Van Wijk and Patterson (1940) and Sayers and Jones (1938) have found that talc particles with a diameter between $5 \mu$ and $0.2 \mu$ are harmful to the pulmonary parenchyma. Estimation of the diameter of the talc particles in the samples by Professor Bonnevie by the Andreasean method gave the following results. Forty-five per cent, of sample No. $1,87 \%$ of sample No. $2,43 \%$ of sample No. 3 , $58 \%$ of sample No. $4,92 \%$ of sample No. 5 , and $98 \%$ of sample No. 6 were composed of talc particles with a diameter of $5 \mu$ or less. A high proportion of the talc particles in our samples are therefore capable of producing injury to the lung parenchyma.

\section{Studies of Pulmonary Function}

The studies of pulmonary function consisted of spirographic examination, chemical analyses of blood, and the determination of the carbon dioxide and oxygen content of the alveolar and the expired air.

The estimations were made with a Benedict spirograph, a Van Slyke's manometric apparatus for blood gas analysis, and the Orsat apparatus for air analysis, and were carried out according to recognized methods (Van Slyke and Neill, 1924). Some of the estimations were carried out both at rest and after exercise. The exercise consisted of stepping up and down 30 times in one minute on to a stool $20 \mathrm{~cm}$. high.

The formula (Cournand and others (1947) used for calculating the predicted values was maximum breathing capacity $(1 . / \mathrm{min})=.186.5-(0.522 \times$ age in years) $\times$ body surface area (sq. m.). The patient's surface area was determined from his weight and height by the Du Bois nomogram.

\section{Analysis of Findings}

As is shown in Table 2 the values for the arterial blood oxygen at rest in Cases 2 and 7 were substantially lower than normal values, and for arterial blood oxygen saturation at rest in Cases 1,2 , and 7 substantially lower than normal. In all the cases the values of the arterial blood oxygen content and the arterial blood oxygen saturation after exercise were found to be much lower than normal. There was a 
definite correlation between these values and the extent of the radiological appearances.

In all cases the transfer gradients were found to be higher than the normal values. Those cases with the more extensive disease had higher transfer gradients. This may be attributed to the inequality of the distribution of oxygen throughout the pulmonary parenchyma owing to the unequal alveolar aeration and the unequal diffusion of air.

As is shown in Table 2 the oxygen consumption decreased with the increase in the extent of pulmonary disease. This may be due to the decreased volume of the air per minute being utilized owing to the destruction of the pulmonary parenchyma and inadequate hyperventilation. The ventilation per minute per square metre of body surface was found to decrease correspondingly with the increase in the extent of disease shown radiologically. The decrease might have been due to insufficient compensatory hyperventilation.

In all our cases the vital capacity was found to be decreased by $19 \%$ to $64 \%$ of the predicted values (Table 2). The maximum breathing capacity (M.B.C.) was found to be decreased by $18 \%$ to $71 \%$ of the predicted values. The greater the extent of pulmonary disease the greater was the variation from the predicted values. In six of our cases the ventilation per minute per square metre of body surface at rest was found to be increased above the normal values (Table 2). We are of the opinion that this increase is a compensatory mechanism to combat the destruction of pulmonary tissue.

\section{Discussion}

Our cases developed talcosis after a short exposure to talc. Exposure in Cases 1, 2, 4, 5, 6, and 8 varied from 16 to 24 months, and in Cases 3 and 7 from 40 to 60 months. Clinical signs of pneumoconiosis were produced within these periods, and radiological signs, such as scattered mottling of the lungs, in some cases becoming confluent, and "tumour-like" appearances, which were demonstrated in three of our cases, were evident within short periods of exposure. The " tumour-like" appearances are indicative of advanced stages of talcosis. The extent of the disease shown radiologically varied with the time of exposure to the talc-polluted atmosphere and also with the extent of the pollution. Cases 1, 2, 3, and 5 had extensive disease, and worked in a heavily polluted atmosphere for varying times. Case 7, who worked as a mechanic for $\mathbf{4 0}$ months, was not exposed to such a heavy talc pollution of the atmosphere as the others and his disease as shown radiologically was not so far advanced.
Follow-up, clinically and radiologically, showed rapid progression of the disease. Radiographs taken at intervals revealed in some cases that the disease progressed from nodule type to "tumour-like" type and there was also a rapid clinical deterioration. One of our patients rapidly deteriorated and died with symptoms of severe pulmonary failure (Case 3).

Our observations allow us to state that pneumoconiosis due to talc is a definite disease. Our findings are not in agreement with those of Sorell and others (1943) who, basing their claims on experimental work, state that talc powder cannot produce the pneumoconiotic plaques which are found in silicosis. These workers were never able to produce experimental pulmonary fibrosis due to talc. For this reason they claimed that pulmonary fibrosis cannot be produced by inhalation of talc if the lung tissue is healthy. They, however, suggested that if pulmonary tuberculosis or other disease which disturbs the bronchial excretion is present, then prolonged exposure to talc may produce talcosis.

More recent research has shown that there is such a clinical entity as talcosis. Our observations confirm more recent work (Gardner, 1938 ; Policard, 1940; Parmeggiani, 1948; Bruusgaard and SkjelbredKnudsen, 1949 ; McLaughlin and others, 1949 ; Baader, 1950) and encourage us to accept the fact that talc can produce a fibrotic pneumoconiosis with functional disturbances.

In our cases the radiological appearances of talcosis were similar to those of silicosis. The lung fields in early cases showed mottling and in more advanced cases " tumour-like" appearances such as are commonly found in silicosis. This agrees with the findings of Pruvost (1946) but Nuck and Szcepanski (1939) describe linear shadowing on the $x$-ray appearance such as is found in asbestosis. We attribute the characteristic $x$-ray appearances to the rapid progression of the disease and the appearance of lesions in both the interstitial pulmonary tissue and pulmonary parenchyma. Fletcher, Mann, Davies, Cochrane, Gilson, and Hugh-Jones, (1949) suggested that secondary tuberculosis is responsible for the "tumour-like" $x$-ray appearances. In our cases, some of which had these " tumour-like" appearances, there was no evidence of secondary tuberculosis, but it is known that cases of progressive massive fibrosis in coal miners have repeatedly negative sputa for $M$. tuberculosis in spite of the fact that pathological examination revealed tuberculosis.

We are of the opinion that the "tumour-like" appearances on the radiographs of some of our cases was due not to fibrosis alone but to concretions 
of talc obstructing the bronchioles and causing areas of atelectasis, this being responsible for a further secondary fibrosis which results in increasing the fibrotic tissue already present due to irritation of the pulmonary parenchyma by the inhalation of talc.

The rapid development and progression of pneumoconiosis due to talc in our cases must be attributed to the lack of preventive measures taken against the inhalation of the powder, to the high concentration of talc particles in the atmosphere with a diameter of $5 \mu$ or less, and also to the high content of silicates in the talc as shown by analyses. Chemical analyses of our talc samples have shown that there is no free silicic acid in this talc. According to the majority of writers free silicic acid is the causative factor in the production of silicosis.

Our analyses of pulmonary function studies are indicative generally of several degrees of impaired pulmonary function. The results of the analysis of these findings suggest that ventilatory as well as alveolar respiratory insufficiency was present. It is possible that the fibrotic changes found in talcosis produce changes in alveolar aeration and perfusion. It is evident that this is an important factor in the production of pulmonary insufficiency.

\section{Summary}

Eight cases of talcosis occurring in mill workers and developing after an unusually short exposure to talc are described.

The radiological appearances and clinical findings in these cases were similar to those found in silicosis.

The chemical analyses of samples of talc powder did not reveal the presence of free silicic acid. It was evident that the gross pollution of the air in the factories and the small diameter of the talc particles were the main contributory factors in the production of talcosis.
Talcosis may be considered a type of fibrotic pneumoconiosis accompanied by functional disturbances.

We wish to express our gratitude to Dr. Paul Bonnevie, Professor of Hygiene in the University of Copenhagen, for his help in this work.

\section{REFERENCES}

Baader, E. W. (1950). Dtsch. med. Wschr., 75, 50.
Bruusgaard, A.. and Skjelbred-Knudsen, K. B. (1949). Proceedings of the IX Int. Congr. on Industr. Med., 1948, London, p. 755. Wright, Bristol.

Cavigneaux, Charles, Fuchs, and Tara, S. (1950). Arch. Mal. prof. 11,34 .

Cournand,-(1947). J. Thorac. Surg., 16, 2.

Cunningham. Quoted by Zanelli (1931)

Dreessen, W. C. (1933). J. industr. Hyg., 15, 66

, and Dalla Valle, J. M. (1935). Publ. Hith Rep., Wash., 50, 131 her, C. M., Mann, K. J., Davies, I., Cochrane, A. L. Gilson, J. C., and Hugh-Jones, P. (1949). J. Fac. Radiol
. I

Gardner, L. U. (1938). J. Amer. med. Ass., 111, 19

Greenburg, L. (1947). Yale J. Biol. Med.,

Hayhurst (1915). Quoted by Policard, A. (1940). Arch. Mal.

Hogue, W. L., 2, 530. and Mallette, F. S. (1949). J. industr. Hyg., 31, 359.

McLaughlin, A. I. G., Rogers, E., and Dunham, K. C. (1949) British Journal of Industrial Medicine, 6, 184 .

Merewether, E. R. A. (1934). A. R. Chief Insp. Factories for the Year 1933, p. 63. H.M.S.O., London.

(1935). A. R. Chief Insp. Factories for the Year 1934, p. 65. Middleton, E. L. (1936). Lancet, 2, 1, 59.

Millman, N. (1947). Occup. Med., 4, 391.

Nuck, K., and Szcepanski, W. (1939). Talk und Talkstaublunge. Barth, Leipzig.

Pancoast, H. K., and Pendergrass, E. P. (1931). Amer. J. Roentgenol., 26, 556.

Parmeggiani, L. (1948). Rass. Med. industr., 17, 16

Perry, K. M. A. (1947). Thorax, 2, 91.

Policard, A. (1940). Arch. Mal. prof., 2, 530

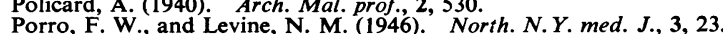

Price,-, and Carpenter,- (1940). Amer. Inst. Min. Metall. Engr tech. Publ., No. 1179 .

Pruvost, P. (1946). Bull. Acad. Méd., Paris, 130, 202.

Sand. Quoted by Devoto and Cesabianchi. National congress in occupational diseases. Turin, 1911

Sayers, R. R., and Jones, R. R. (1938). Publ. Hlth Rep., Wash. $53,1453$.

Schulz, R. Z., and Williams, C. R. (1942). J. industr. Hyg., 24, 75

Siegal, W., S'mith, A. R., and Greenburg, L. (1943). Amer. J. Roentgenol., 49, 11.

Sorel, R., Lasserre, J., and Salvador, A. (1943). Les steatoses. Masson, Paris.

Stüber, K. (1934). J. industr. Hyg., 16, 282.

Thorel, C. (1896). Beitr. Path. Anat., 20, 85. J. biol. Chem., 61, 523

Van Wlyke, D. D., and Neill, J. M. (1924). J. biol. Chem., 61, 523. 22, 31 .

Zanelli, A. (1931). Med. d. Lavoro, 22, 3. 